\title{
Immunohistochemical Analysis of Human Homologue of Drosophila Patched (PTCH) in Dental Follicles of Impacted Third Molars
}

\author{
Análisis Imunohistoquímico del Homólogo Humano del Gen Parcheado \\ de Drosofila (PTCH) en Folículos Dentales de Terceros Molares Retenidos \\ "David Moraes de Oliveira; *Márcia Maria Ferreira da Silveira; *Emanuel Sávio de Souza Andrade; *Ana Paula Veras Sobral; \\ ** Paulo Ricardo Saquete Martins-Filho; ${ }^{* * *}$ Thiago de Santana Santos; *Patrícia Leimig Amorim de Oliveira; \\ ${ }^{* *}$ Aline Carvalho Peixoto; * Jadson Alípio Santana de Souza Santos \& **Marta Rabello Piva
}

OLIVEIRA, D. M.; SIVEIRA, M. M. F.; ANDRADE, E. S. S.; SOBRAL, A. P. V.; MARTINS-FILHO, P. R. S.; SANTOS, T. S.; OLIVEIRA, P. L. A.; PEIXOTO, A. C.; SANTOS, J. A. S. S. \& PIVA, M. R. Immunohistochemical analysis of human homologue of drosophila patched (PTCH) in dental follicles of impacted third molars.Int. J. Morphol., 30(1):105-109, 2012.

SUMMARY: This study investigated the immunodetection of PTCH in epithelial components of dental follicles associated with impacted third molars without radiographic signs of pathosis. One hundred and five specimens of dental follicles associated with impacted third molars with incomplete rhizogenesis (between Nolla's stage 6 and 9) were surgically removed from 56 patients. Epithelial cell proliferation was determined by using immunohistochemical labeling. Statistical analysis was performed using Fisher exact test and a level of significance of 5\%. Of the 105 dental follicles collected, 3 were PTCH-positive. The specimens with squamous metaplasia and epithelial hyperplasia had higher rates of positivity for PTCH, as well as those with active remnants of odontogenic epithelium. This study suggests that the odontogenic cells of the dental follicle might be proliferating during the rhizogenesis, while the squamous metaplasia and hyperplasia of the epithelial lining and proliferative odontogenic epithelial rests show the differentiation potential of dental follicles.

KEY WORDS: Immunohistochemistry; Dental follicle; Odontogenic epithelial; PTCH.

\section{INTRODUCTION}

The human homologue of Drosophila patched (PTCH) is a tumor suppressor gene localized to chromosome 9q22.3-q31 (GenBank accession numbers: U43148 and U59464) (Hahn et al., 1996; Johnson et al., 1996) member of the Hedgehog/Patched (or SHH/SMO/PTCH) signaling pathway, which plays a fundamental role during embryogenic development and appears to underlie many disease states when misregulated (Saldanha, 2001). Increased PTCH expression has been detected immunohistochemically in sporadic and Gorlin-syndrome-related keratocystic odontogenic tumors (Barreto et al., 2000; Ohki et al., 2004; Shear, 2002; Zedan et al., 2001), dentigerous cysts (Levanat et al., 2000), ameloblastomas (Kumamoto et al., 2004) and epithelial-mesenchymal tumors, such as adenomatoid odontogenic tumor, Pindborg tumor and ghost cell odontogenic carcinoma (Zhang et al., 2006). However, to the best of our knowledge, there are no studies concerning the PTCH in dental follicles (DF), whose epithelial components are closely related to the development of these odontogenic lesions.

Taking into consideration that the radiograph is in most cases the only instrument available to the oral and maxillofacial surgeon for deciding between removing or following up an asymptomatic impacted tooth and that a number of studies show the possibility of cystic degeneration and/or neoplastic transformation of the follicles, the present study investigated the immunodetection of PTCH in epithelial components of DF associated with impacted third molars without radiographic signs of pathosis.

\footnotetext{
* School of Dentistry, University of Pernambuco, Camaragibe, Brazil.

** School of Dentistry, Federal University of Sergipe, Aracaju, Brazil.

*** School of Dentistry, University of São Paulo, Ribeirão Preto, Brazil.
} 
OLIVEIRA, D. M.; SIVEIRA, M. M. F.; ANDRADE, E. S. S.; SOBRAL, A. P. V.; MARTINS-FILHO, P. R. S.; SANTOS, T. S.; OLIVEIRA, P. L. A.; PEIXOTO, A. C.; SANTOS, J. A. S. S. \& PIVA, M. R. Immunohistochemical analysis of human homologue of drosophila patched (PTCH) in dental follicles of impacted third molars.Int. J. Morphol., 30(1):105-109, 2012.

\section{MATERIAL AND METHOD}

The sample consisted of orthodontic patients with indication for impacted third molar removal. Only patients with impacted third molars with incomplete rhizogenesis (between Nolla's stage 6 and 9) and without evidence of abnormal pericoronal radiolucency (follicular space $<4 \mathrm{~mm}$ ) were included in this study. The follicular space was measured using ortopantomography and determined from the half of the mesial, distal and occlusal surfaces, the largest width being selected. Exclusion criteria were patients with third molars with symptoms and / or radiographic signs outside normal pattern.

56 patients (17 males and 39 females) underwent removal of impacted third molars, amounting 105 dental follicles. Ages ranged from 13 to 24 years, with a mean of 18.3 years ( standard deviation $=2.7$ years) and a median of 18 years.

The follicles were separated from the tooth by making an incision at the level of the cementoenamel junction, conditioned in $10 \%$ formol and routinely stained with hematoxylin and eosin (HE). The epithelial lining of the specimens were classified according to the type (absent, enamel reduced and stratified squamous) and cell activity (hyperplastic and inactive). The remaining epithelium in the connective tissue was classified as inactive or proliferative when present (de Oliveira et al., 2011).

Immunohistochemical staining was performed using the streptavidin-biotin method. Briefly, after the $3 \mathrm{~mm}$ sections were deparaffinized in xylene and dehydrated in ethanol, endogenous peroxidase activity was blocked by incubating sections for $15 \mathrm{~min}$ in $0.3 \%$ ( $\mathrm{vol} / \mathrm{vol}$ ) hydrogen peroxide in methanol. The sections were then incubated with primary antibodies to PTCH (Santa Cruz Biotechnology, Santa Cruz, CA, USA) for $60 \mathrm{~min}$ at room temperature and then stained according to the streptavidin-biotin method. The immunoreaction was visualized with diaminobenzedine (Dako Corporation, Carpinteria, CA, USA) as a chromogen. The slides were counterstained with Mayer's hematoxylin solution and mounted in Entellan (Merck KGaA, Darmstadt, Germany). For negative control the primary antibody was omitted and as positive control sections of keratocystic odontogenic tumor were used. Brown cytoplasmic staining, regardless of intensity, was considered PTCH-positive.

Statistical analysis was performed using Fisher's Exact Test and a level of significance of 5\%. This work was previously submitted and approved by ethical committee in research from Pernambuco University by number 220/03.

\section{RESULTS}

Histopathological analysis revealed that of the 105 DF collected, 24 showed no epithelial lining, 66 presented reduced enamel epithelium and 15 stratified squamous epithelium. Hyperplastic activity, proliferative odontogenic epithelial rests in the connective tissue and inflammation were observed in $16.7 \%, 5.7 \%$ and $21.3 \%$ of the cases, respectively (Table I).

Table I. Distribution of histopathological variables of the DF. $n=$ number of DF.

\begin{tabular}{lcc}
\hline Variables & $\mathbf{n}$ \\
\hline Type of Epithelial Lining & $\begin{array}{c}\text { Stratified Squamous } \\
\text { Epithelium } \\
\text { Reduced Enamel } \\
\text { Epithelium }\end{array}$ & 15 \\
& Hyperplastic & 66 \\
$\begin{array}{l}\text { Cell Activity of Epithelial } \\
\text { Lining }\end{array}$ & Inactive & 65 \\
$\begin{array}{l}\text { Odontogenic Epithelial } \\
\text { Rests }\end{array}$ & Proliferative & 5 \\
\hline
\end{tabular}



Fig. 1. (a) PTCH cytoplasmatic staining in hyperplastic stratified squamous epithelium. There is no staining in connective tissue (SABC/100x). (b) PTCH cytoplasmatic staining in reduced enamel epithelium (SABC/400x). 
OLIVEIRA, D. M.; SIVEIRA, M. M. F.; ANDRADE, E. S. S.; SOBRAL, A. P. V.; MARTINS-FILHO, P. R. S.; SANTOS, T. S.; OLIVEIRA, P. L. A.; PEIXOTO, A. C.; SANTOS, J. A. S. S. \& PIVA, M. R. Immunohistochemical analysis of human homologue of drosophila patched (PTCH) in dental follicles of impacted third molars.Int. J. Morphol., 30(1):105-109, 2012.

Immunohistochemical analysis showed that $3 \mathrm{DF}$ were PTCH-positive (2.85\%). Two cases were excluded due to problems in the antigen retrieval. In one case of DF PTCHpositive, the specimen presented hyperplastic stratified squamous epithelium. In the second case, PTCH cytoplasmatic staining was expressed in reduced enamel epithelium. In the third case, the odontogenic epithelial rests showed squamous metaplasia (Table II) (Fig. 1).
No statistically significant difference was found between rhizogenesis stage and PTCH staining. Although the relative frequency was higher in DF PTCH-positive with squamous stratified epithelium, hyperplastic activity and proliferative odontogenic epithelial rests, we also found no statistical associations between these histopathological variables and PTCH staining.

Table II. Characteristics of DF PTCH-Positive.

\begin{tabular}{lccc}
\hline DF PTCH-Positive & Type of Epithelial Lining & Cell Activity of Epithelial Lining & Odontogenic Epithelial Rests \\
\hline Case 1 & SSE & Hyperplastic & Inactive \\
Case 2 & REE & Hyperplastic & Inactive \\
Case 3 & SSE & Hyperplastic & Proliferative \\
\hline
\end{tabular}

\section{DISCUSSION}

Removal of impacted third molars is a common procedure in oral surgery. In the presence of pathological changes and/or severe symptoms, such as infection, nonrestorable carious lesions, cysts, tumors and destruction of adjacent teeth and bone, there are no doubts about the real need for removal of these teeth. However, the justification for prophylactic removal of impacted third molar is less certain and has been debated for many years (NHS, 1999).

Although several authors have reported that the risk of the development of cysts and tumors around third molars is extremely low (Güven et al., 2000; Kostopoulou et al., 2000; Stephens et al., 1989), others observed a high incidence of pathological changes in the DF, especially associated with the dentigerous cyst (DC) (Baykul et al., 2005; Daley \& Wysocki, 1995; Glosser \& Campbell, 1999). However, the discrepancy in the incidence rates of pathological changes in the DF is due to lack of standardization in the methods of these studies that used different parameters for radiographic and histological analysis of the cases.

Few authors have studied the proliferative potential of the DF associated to the impacted third molars using immunohistochemical methods, but there are no studies that identify the presence of mutations in PTCH gene in DF. The use of cell proliferating markers, such as integrins (Godoy et al., 2007), Ki-67 (Cabbar et al., 2008; Edamatsu et al., 2005) and PCNA (Adelsperger et al., 2000), has shown that the squamous metaplasia would be the first visible sign of cystic transformation of the DF and not a normal change due to advanced age. In our study, although we have not found a statistical association between PTCH labeling and the type of epithelial lining, probably due to the low number of PTCH-positive cells, the specimens with squamous metaplasia had higher rates of positivity for PTCH than DF with reduced enamel epithelium. Our results suggest that these follicles with squamous metaplasia could represent, at this stage of rhizogenesis, early signs of development of odontogenic lesions, since the immunoexpression of PTCH may indicate a failure in cell cycle regulation. On other hand, there is no way to predict that PTCH-negative follicles remain unchanged if they are left in situ.

Our results also indicate a higher rate of PTCHpositive cells in the presence of epithelial hyperplasia, in agreement with the findings of Edamatsu et al., who found a high proliferative potential of follicles with proliferating rete processes through the use of Ki-67.

In conclusion, despite of the low sample of this study, it can be suggested that the odontogenic cells of the dental follicle might be proliferating during the rhizogenesis, while the squamous metaplasia and hyperplasia of the epithelial lining and proliferative odontogenic epithelial rests show the differentiation potential of dental follicles.

\section{ACKNOWLEDGEMENTS}

We are thankful to CNPq and CAPES for financial support to execute this study. 
OLIVEIRA, D. M.; SIVEIRA, M. M. F.; ANDRADE, E. S. S.; SOBRAL, A. P. V.; MARTINS-FILHO, P. R. S.; SANTOS, T. S.; OLIVEIRA, P. L. A.; PEIXOTO, A. C.; SANTOS, J. A. S. S. \& PIVA, M. R. Immunohistochemical analysis of human homologue of drosophila patched (PTCH) in dental follicles of impacted third molars.Int. J. Morphol., 30(1):105-109, 2012.

OLIVEIRA, D. M.; SIVEIRA, M. M. F.; ANDRADE, E. S. S.; SOBRAL, A. P. V.; MARTINS-FILHO, P. R. S.; SANTOS, T. S.; OLIVEIRA, P. L. A.; PEIXOTO, A. C.; SANTOS, J. A. S. S. \& PIVA, M. R. Análisis imunohistoquímico del homólogo humano del gen parcheado de drosofila $(\mathrm{PTCH})$ en folículos dentales de terceros molares retenidos. Int. J. Morphol., 30(1):105-109, 2012 .

RESUMEN: Se investigó la inmunodetección de PTCH en los componentes epiteliales de los folículos dentales asociados a terceros molares retenidos sin signos radiográficos y morfológicos de patología. Fueron quirúrgicamente extraídos de 56 pacientes 105 muestras de folículos dentales asociadas a terceros molares retenidos con rizogénesis incompleta (entre el estadio de Nolla 6 y 9). La proliferación de células epiteliales se deteminó mediante inmunohistoquímica. El análisis estadístico se realizó mediante la prueba exacta de Fisher. De los 105 folículos dentales recogidos, 3 fueron PTCH-positivos. Las muestras con metaplasia escamosa e hiperplasia epitelial tuvieron mayores tasas de positividad para PTCH, así como aquellos con los restos de proliferación del epitélio odontogénico. En conclusión, este estudio sugiere que las células odontogénicas del folículo dental podrían estar proliferando durante la rizogénesis, mientras que la metaplasia escamosa e hiperplasia del epitelio y de restos epiteliales odontogénicos en proliferación muestran el potencial de diferenciación de los folículos dentales.

PALABRAS CLAVE: Inmunohistoquímica; Saco Dental; Tercer Molar.

\section{REFERENCES}

Adelsperger, J.; Campbell, J. H.; Coates, D. B.; Summerlin, D. J. \& Tomich, C. E. Early soft tissue pathosis associated with impacted third molars without pericoronal radiolucency. Oral Surg. Oral Med. Oral Pathol. Oral Radiol. Endod., 89:402-6, 2000 .

Barreto, D. C.; Gomez, R. S.; Bale, A. E.; Boson, W. L. \& De Marco, L. PTCH gene mutations in odontogenic cysts. J. Dent. Res., 79:1418-22, 2000

Baykul, T.; Saglam, A. A.; Aydin, U. \& Bas,ak, K. Incidence of cystic changes in radiographically normal impacted lower third molar follicles. Oral Surg. Oral Med. Oral Pathol. Oral Radiol. Endod., 99:542-5, 2005.

Cabbar, F.; Güler, N.; Comunog `lu, N.; Sençift, K. \& Çölog`lu, S. Determination of potential cellular proliferation in the odontogenic epithelia of the dental follicle of the asymptomatic impacted third molars. J. Oral Maxillofac. Surg., 66:2004-11, 2008.

Daley, T. D. \& Wysocki, G. P. The small dentigerous cyst. A diagnostic dilemma. Oral Surg. Oral Med. Oral Pathol. Oral Radiol. Endod., 79:77-81, 1995.

de Oliveira, D. M.; da Silveira, M. M. F.; Andrade, E. S. S.; Sobral, A. P. V.; Martins-Filho, P. R. S.; Santos, T. S. \& de Oliveira, P. L. A. Immunohistochemical analysis of proliferating cell nuclear antigen $8 \mathrm{PCN}$ ) in dental follicles of impacted third molars. Int. J. Morphol., 29(2):526-31, 2011.

Edamatsu, M.; Kumamoto, H.; Ooya, K. \& Echigo, S. Apoptosisrelated factors in the epithelial components of dental follicles and dentigerous cysts associated with impacted third molars of the mandible. Oral Surg. Oral Med. Oral Pathol. Oral Radiol. Endod., 99:17-23, 2005.
Glosser, J. W. \& Campbell, J. H. Pathologic change in soft tissues associated with radiographically 'normal' third molar impactions. BR. J. Oral Maxillofac. Surg., 37:259-60, 1999.

Godoy, G. P.; da Silveira, E. J.; Lins, R. D.; de Souza, L. B.; de Almeida Freitas, R. \& Queiroz, L. M. Immunohistochemical profile of integrins in enlarged dental follicle and dentigerous cysts. Oral Surg. Oral Med. Oral Pathol. Oral Radiol. Endod., 104:e29-34, 2007.

Güven, O.; Keskln, A. \& Akal, U. K. The incidence of cysts and tumors around impacted third molars. Int. J. Oral Maxillofac. Surg., 29:131-5, 2000.

Hahn, H.; Wicking, C.; Zaphiropoulos, P. G.; Gailani, M. R.; Shanley, S.; Chidambaram, A.; Vorechovsky, I.; Holmberg, E.; Unden, A. B.; Gillies, S.; Negus, K.; Smyth, I.; Pressman, C.; Leffell, D. J.; Gerrard, B.; Goldstein, A. M.; Dean, M.; Toftgard, R.; Chenevix-Trench, G.; Wainwright, B. \& Bale, A. E. Mutations of the human homolog of Drosophila patched in the nevoid basal cell carcinoma syndrome. Cell, 85:841-51, 1996.

Johnson, R. L.; Rothman, A. L.; Xie, J.; Goodrich, L. V.; Bare, J. W.; Bonifas, J. M.; Quinn, A. G.; Myers, R. M.; Cox, D. R.; Epstein, E. H. Jr. \& Scott, M. P. Human homolog of patched, a candidate gene for the basal cell nevus syndrome. Science, 272:1668-71, 1996.

Kostopoulou, O.; Brickley, M. R.; Shepherd, J. P. \& Newcombe, R. G. Perceived risk of future pathology associated with pathology-free third molars: A comparison of oral and maxillofacial surgeons and family dentists. $B r$. Dent. J., 188:28-31, 2000. 
OLIVEIRA, D. M.; SIVEIRA, M. M. F.; ANDRADE, E. S. S.; SOBRAL, A. P. V.; MARTINS-FILHO, P. R. S.; SANTOS, T. S.; OLIVEIRA, P. L. A.; PEIXOTO, A. C.; SANTOS, J. A. S. S. \& PIVA, M. R. Immunohistochemical analysis of human homologue of drosophila patched (PTCH) in dental follicles of impacted third molars.Int. J. Morphol., 30(1):105-109, 2012.

Kumamoto, H.; Ohki, K. \& Ooya, K. Expression of sonic hedgehog (SHH) signaling molecules in ameloblastomas. J. Oral Pathol. Med., 33:185-90, 2004.

Levanat, S.; Pavelic', B.; Crnic', I.; Oreskovic', S. \& Manojilovic', $\mathrm{S}$. Involvement of PTCH gene in various noninflammatory cysts. J. Mol. Med., 78:140-6, 2000.

NHS. Centre for Reviews and Dissemination, University Of York. Prophylactic Rremoval of impacted third molars: is it justified? Effectiveness matters. Br. J. Orthod., 26:149-51, 1999.

Ohki, K.; Kumamoto, H.; Ichinohasama, R.; Sato, T.; Takahashi, N. \& Ooya, K. PTCH gene mutations and expression of SHH, PTC, SMO and GLI-1 in odontogenic keratocysts. Int. J. Oral Maxillofac. Surg., 33:584-92, 2004.

Saldanha, G. The hedgehog signaling pathway in cancer. J. Pathol., 193:427-32, 2001.

Shear, M. The aggressive nature of the odontogenic keratocyst: is a benign cystic neoplasm? Part. 2. Proliferation and genetic studies. Oral Oncol., 38:323-31, 2002.

Stephens, R. G.; Kogon, S. L. \& Reid, J. A. The unerupted or impacted third molar - a critical appraisal of its pathologic potential. J. Can. Den. Assoc., 55:201-7, 1989.

Zedan, W.; Robinson, P. A.; Markham, A. F. \& High, A. S. Expression of sonic hedgehog receptor "PATCHED" in basal cell carcinomas and odontogenic keratocysts. J. Pathol., 194:473-7, 2001.

Zhang, L.; Chen, X. M.; Sun, Z. J.; Bian, Z.; Fan, M. W. \& Chen, Z. Epithelial expression of SHH signaling pathway in odontogenic tumors. Oral Oncol., 42:398-408, 2006.

\section{Correspondence to:}

Dr. Emanuel Sávio de Souza Andrade Faculdade de Odontologia de Pernambuco Universidade de Pernambuco.

Av. General Newton Cavalcanti, 1650

Camaragibe - Pernambuco. CEP: 54753-220

BRAZIL

Email: thiago.ctbmf@yahoo.com.br

Received: 20-04-2011

Accepted: 21-11-2011 